\title{
Sacrificial Scripts, Blood Values and Gender in the Twilight Vampire Narrative
}

\author{
Grietje Dresen
}

\section{1 \\ Introduction}

I'd never given much thought to how I would die. But dying in the place of someone I love seems like a good way to go.

These sentences, pronounced by protagonist Bella Swan in the overture to the first Twilight film, are a forecast of things to come. Above all, they forecast the role Bella is going to play throughout the Twilight Saga, willingly sacrificing (or at least risking) her life for the ones she loves: For her mother, her beloved vampire fiancé Edward, and her unborn, half-vampire child. The sentences in the overture echo the Preface in the first Twilight novel, where the same thoughts are expressed in the context of a mysterious scene in which the 'I'-figure (appearing to be Bella) is being threatened by a 'hunter'. In the prologue to the film, this impression of being hunted is symbolized by the accompanying imagery, showing a defenceless deer chased through a dark wood.

In this chapter, I intend to analyse the sacrificial scripts that underlie the storyline in the Twilight Saga, an immensely popular vampire narrative devoured by millions of mainly female adolescents all over the world. From the moment I saw the first Twilight screenplay together with my daughter, I was struck by Bella's unhesitating willingness to sacrifice her life, announced (in Bella's voice) in the prologue. Of course my view is affected by the fact that I am a scholar of religion, and a gender scholar too. From that perspective, the gender scripts in the Twilight book series and film versions seem astonishingly conventional at first sight. Bella is presented as an average, rather clumsy high school student, alternately submissive and self-conscious to her male counterparts, and eager to sacrifice herself at crucial moments in the series. By contrast, the main male characters are depicted as supermen, strong, fast and brave (in fact superhuman), and utterly in control. Nevertheless, millions of teen-aged girls throughout the world adore the story and its characters.

Is their adoration to be explained as a longing to return to traditional gender roles, as a correction to both outdated feminism and post-feminism? Does the Saga appeal to an everlasting desire in (young) women to be safeguarded by a hero against the evils that come with adulthood? Many feminist reviewers 
criticized the romantic idealization of Bella's awkwardness in Twilight, namely her constant need of male protection - protection from her own sexual desires, to begin with. Still, we should assume the countless fans to be modern, emancipated young adults, not victims of false consciousness. So, what is it that fascinates them?

Before I continue outlining my questions, let me briefly introduce the Twilight phenomenon. Speaking of 'Twilight' in general, I refer to the four-book series, the screen adaptations, and an online partial draft (see below). The first volume and film were also called Twilight. I refer to this first volume in italics. Twilight was published in 2005. ${ }^{1}$ Three volumes followed quickly, New Moon (2006), Eclipse (2007) and Breaking Dawn (2008)..$^{2}$ On her website, the Twilight creator, Stephenie Meyer, published what she called "my original character development exercise, Edward's version of Bella's [story]" 3 - Twilight is written from Bella's perspective. ${ }^{4}$ This version in Edward's voice, picturing his harsh inner conflicts and ordeal, is titled Midnight Sun.

Up to now, ${ }^{5}$ four Twilight screen adaptations have been released, in 2008 , 2009, 2010 and 2011 respectively. These films added a lot to the world-wide hype; the actors cast for the main characters ${ }^{6}$ are worshipped as if they were the godlike creatures they play. The last novel is filmed in two parts; part II of this Breaking Dawn adaptations will be released on November 16, 2012.

The plot of the Twilight vampire narrative is basically romantic: A common high school student, Bella Swan, falls in love with a gorgeous fellow student, who appears to be a vampire, and a 'good' vampire too. He and his family (all

1 I refer to the British Atom paperback editions. Twilight was first published in the U.s. by Little, Brown. In, Twilight (ed. S. Meyer; London: Atom, 2007), the page numbers differ slightly from the original Little, Brown edition. In the other volumes I quote, page numbers do not differ from the original editions.

2 Stephenie Meyer, New Moon (London: Atom, 2006; 2007); Stephenie Meyer, Eclipse (London: Atom, 2007; 2008); Stephenie Meyer, Breaking Dawn (London: Atom, 2008).

3 See www.stepheniemeyer.com, Midnight Sun, Partial Draft 4 (2008) and Meyer's comments. She published this draft (retelling the first half of Twilight) in response to illegal distribution.

4 The Epilogue in Eclipse and the middle part in Breaking Dawn are written from the perspective of Bella's werewolf friend Jacob.

5 November 2011.

6 Kristen Stewart (Bella Swan), Robert Pattinson (Edward Cullen) and Taylor Lautner (Jacob Black). The Twilight franchise successfully exploits their immense popularity. 
bitten to vampire-existence by the compassionate 'father', Dr Cullen, because they were dying of some other cause) are self-declared 'vegetarians' who do not consume human blood. They live on a diet of animal blood, gathered during periodic hunts, although this blood tastes to them like "tofu and soy milk" to humans. ${ }^{7}$ Abstaining from human blood is a never-ending ordeal they suffer deliberately, because they don't want to be 'monsters'. Their rigorous moral choice sets them apart from their kind by creating unique reciprocal 'blood' relations, unknown amongst cold ones, namely bonds of love. The Cullen family is a living (or rather, undead) example of how a family should be, headed by a father, described by Edward as "a leader who deserved following", a mother who "made that following into an act of love", and linked together by everlasting ties of love and mutual care. ${ }^{8}$

Bella and Edward meet after Bella has moved from sunny Phoenix, where she lived with her mother, to her father living in misty Forks in the northwest of Washington State. Edward and his vampire brothers and sisters attend high school in Forks. Bella immediately attracts Edward's attention because he cannot read her mind, as he can with all other humans and vampires. Bella appears to have another attractive, but alarming quality: The scent of her skin, her blood drives Edward mad with bloodlust. Nevertheless they fall in love, and this causes many problems, especially for Edward; how to hide his vampire state, and above all, how to control his burning bloodlust? As the plot of Twilight unfolds, the first problem is solved by Bella's attentiveness. The latter problem, though, underpins the Twilight scenario till at least the end of the second volume. The solution to all Edward's external problems and inner conflicts would be to transform Bella into a vampire, and this is what she herself desperately wants, from the moment she is aware of Edward's condition. Edward considers it to be selfish to transform Bella, however, since he knows the consequences - excruciating, unendurable inner burning during the transformation process, and endless existence "without soul", as a 'monster'. He refuses to transform her, up to the moment Bella is dying in childbirth, in the last volume. By becoming a vampire, Bella changes from the clumsy girl she was into a creature she senses to be her true self, her true nature. She becomes an undead supergirl, "a carving of a goddess",9 outdoing her new family as to

7 Meyer, Twilight, 164 .

8 Meyer, Midnight Sun, 78. Cf. Carrie A. Platt, "Cullen Family Values: Gender and Sexual Politics in the Twilight Series," in Bitten by Twilight: Youth Culture, Media, \& the Vampire Franchise (eds M. A. Click, J. Stevens Aubrey, and E. Behm-Morawitz; New York (etc.): Peter Lang, 2010), $71-86$.

9 Meyer, Breaking Dawn, 403. 
self-control. Her characteristic unselfishness, though, she takes with her into immortality.

\section{Sacrificial Scripts, Blood Values and the Twilight Attraction}

Engaging with the main questions in this book, I focus on the sacrificial scripts in the Twilight Saga. ${ }^{10}$ As I noted - and I am not the only critic to do so - the scripts in this atypical vampire narrative are highly gendered. In the following sections, I will display the features of these gender dynamics within the staging of (self-)sacrifice in Twilight. I will subsequently clarify what I mean by "blood values", a notion I make use of in another sense than the usual one, applied in medical blood test results. I will use the term in line with Julia Kristeva's psycho-semiotic analysis of the dynamics of 'abjection' in horror,11 Nancy Jay's anthropological studies on the function of blood sacrifice as "birth done better, ${ }^{\prime \prime}$ and religious studies analyses of the ambivalent, gendered valuation of blood in ritual contexts. ${ }^{13}$

\subsection{Self-Sacrifice: Bella's Part}

All feminist critics point to the worrying glorification of Bella's selfless character in the Twilight narrative. This selflessness (also noticed by Edward, and fiercely admired by him ${ }^{14}$ ) shows in several ways. First of all, there is Bella's readiness to sacrifice her life for the sake of those she loves. Her resolute but jeopardizing bravery determines the plot in all four volumes. The two male protagonists are brave too, of course; but Bella's bravery is defined within a

10 Meyer herself pointed out that sacrifice is a main topic in Twilight: "Unconsciously I put a lot of my beliefs into the story. Free agency is a big theme, as is sacrifice" (quoted in A. J. Grant, "Focus on the Family: Good and Evil Vampires in the Twilight Saga," in Vader, Voldemort and other Villains: Essays on Evil in popular Media (ed. J. Heit; Jefferson N. C.: McFarland, 2011), 64-79 (67). Meyer is an active member of the Mormon Church.

11 Julia Kristeva, Powers of horror: An Essay on Abjection (New York: Columbia University Press, 1982).

12 Nancy Jay, Throughout Your Generations Forever: Sacrifice, Religion and Paternity (Chicago \& London: University of Chicago Press, 1992).

13 See e.g. K. de Troyer, J. A. Herbert, J. A. Johnson, and A.-M. Korte, eds, Wholly Woman, Holy Blood: A Feminist Critique of Purity and Impurity (Harrisburg: Trinity Press International, 2003) and bibliography therein.

14 Meyer, Midnight Sun, 92-93. 
format of female martyrdom, defenceless but unyielding, and thus powerful. ${ }^{15}$ Aside from this outspoken disposition to actually and vicariously sacrifice herself, there is the day-to-day unselfishness that Edward considers to be Bella's ultimate attraction, but feminist critics deplore above all. To quote just one of them, namely Bonnie Mann, stating in an article in which she confronts Bella's character with Simone de Beauvoir's The Second Sex:

What is disheartening about Meyer's book is her reinstatement of this old promise: Assume your status as prey, as object, and you will gain your freedom as subject (...). Bella (...) is literally torn to shreds by the needs and desires of others. (...) But how does one open the door of the feminine imagination for young women so that they might trace paths to themselves that don't pass through traditional feminine annihilation? (...) [I]n her insistence on resurrecting the promise that a meaningful life comes through self-annihilation in the interests of others, [Meyer] promises our daughters the same things our mothers were promised. In that sense, the wild success of Twilight might be cause for despair. ${ }^{16}$

This concern can be heard throughout most gender-critical reviews of the series. Against this emphasis on Bella's selflessness, though, should also be pointed to her confidence and self-protection, which are present from the first pages of Twilight onwards in the form of the fictional 'shield' that protects her consciousness, not only from Edward, but from other vampire intruders too (as becomes apparent later on in the series). Missing this aspect in Bella's character results in missing her most powerful gift, the one that will bring the final battle to a close. I come back to Bella's fictional "mind shield" later.

\subsection{Self-Sacrifice: Edward's Part}

Self-sacrifice is not an all-female part in the Twilight drama, though. All along the series is being emphasized and repeated that the Cullen's 'vegetarian' lifestyle is a life of "sacrifice and denial". In the most penetrating way this denial and its torments are depicted in Edward's report of his first encounter with Bella when she unavoidably has to sit next to him in the biology classroom:

15 Cf. L. Stephanie Cobb, Dying to be men: Gender and Language in Early Christian Martyr Texts (New York: Columbia University Press, 2008).

16 Bonnie Mann, "Vampire Love: The Second Sex negotiates the Twenty-First Century," in Twilight and Philosophy: Vampires, vegetarians and the Pursuit of Immortality (eds R. Housel and J. J. Wisnewski; Hoboken, N. J.: John Wiley \& Sons, 2009), 131-145 (143-144). 
Her scent hit me like [a] wrecking ball, like a battering ram. There was no image violent enough to encapsulate the force of what happened to me in that moment. In that instant, I was nothing close to the human I'd once been; no trace of the shreds of humanity l'd managed to cloak myself in remained. I was a predator. She was my prey. There was nothing else in the whole world but that truth. (...) Thirst burned through my throat like fire. My mouth was baked and desiccated. The fresh flow of venom did nothing to dispel that sensation. (...) The face of the monster in me the face I'd beaten back with decades of effort and uncompromising discipline. ${ }^{17}$

The description of this inner torture continues for pages and pages, not least to highlight the ultimate control Edward finally manages to find, for a moment. Being near to Bella continues to be a temptation, but once he comes to love her, he accepts his being tempted as the price he must pay:

I burnt. The burning was acceptable, though. (...) [H]ere she was, still willingly at my side. I owed something in return for that. A sacrifice. A burnt offering. ${ }^{18}$

Throughout the series there is no doubt left as to the extreme self-control Edward needs to be close to Bella, let alone to touch her, or kiss her, or (decently married) make love to her.

The attraction of the series for teenage girls has been explained by pointing to this Jane Austen-like, restrained sexuality, termed as an "erotics of abstinence",19 and regarded as a relief in a culture obsessed with sex. Several critics asserted that the way Edward manages to control his impulses (in order not to kill Bella, but also because he is old school, being born in 1901) makes room for Bella's own dreams and desires. Within this room for Bella's palpitating desires, described in length to the readers, Twilight's adorers may well enjoy theirs, without being hindered by reality. ${ }^{20}$

\footnotetext{
17 Meyer, Midnight Sun, 9-10.

18 Meyer, Midnight Sun, 194.

19 Marc E. Shaw, "For the Strength of Bella? Meyer, Vampires, and Mormonism," in Twilight and Philosophy (eds R. Housel et al.), 227-236 (233). He borrows the term 'erotics of abstinence' from Lev Grossman (Time, April 24, 2008: "Stephenie Meyer, A New J. K. Rowling?").

20 So Joyce A. Mercer, "Vampires, Desire, Girls and God: Twilight and the Spiritualities of Adolescent Girls," Pastoral Psychology 60 (2011): 263-278 (272; 276).
} 
Occasionally Edward's self-discipline is tested to the absolute limit. This is the case, for example, at the end of Twilight, when he has to suck the venom of an evil vampire out of Bella's hand (venom of the 'hunter' from the Preface, who lured Bella by falsely suggesting he had got hold of her mother and trapped her with the intention of killing and draining her). Faced with this ordeal, Edward hesitates, his face "twisted into a mask of indecision and pain". ${ }^{21} \mathrm{He}$ fears that he will not be able to stop sucking Bella's alluring blood, yet, encouraged by his father who is giving medical care to Bella, "the doubt was suddenly replaced with a blazing determination".22 Actually Bella regrets his awesome self-control; she had rather had the venom spread, so she could have become his equal. For Edward, however, loving Bella means he cannot possibly let that happen. The asceticism of the Cullens might make them less monstrous, but that does not mean vampire existence should be thought of as good, he keeps stating. "We [the Cullen family] would trade anything to be human". ${ }^{23}$

The sacrificial scenarios in the Cullen's "life of sacrifice", ${ }^{24}$ and particularly in Edward's blazing determination, differ from the 'feminine', selfless, defenceless-but-uncompromising martyrdom that characterizes those of Bella. ${ }^{25}$ One could say that Edward's self-sacrificial love for Bella in a way suffers from too much self, too much determination, too much "mind over matter", ${ }^{26}$ in short, too much control. This control is not only exerted on his own vampire urges, but is directed at Bella too, in the name of her alleged "devastating vulnerability". ${ }^{27}$

Occasionally, Bella protests against this constant control, but her protest is far from adequate, according to most critics of the series. Several critics even stress that Edward's protective, intrusive kind of love is just the kind against which young women should be warned. ${ }^{28}$

\footnotetext{
$21 \quad$ Meyer, Twilight, 397.

22 Meyer, Twilight, 397.

23 Meyer, Midnight Sun, 363.

24 Meyer, Breaking Dawn, 718.

25 Bella "wasn't [even] the average martyr - she didn't want an audience to her pain." Meyer, Midnight Sun, 44.

26 Title of chapter 14 in Twilight (cf. 262; 263).

27 Meyer, Midnight Sun, 212 ("Silk over glass ... frighteningly breakable").

28 Edward's criticized dominance shows in such sentences as, "What Bella wanted and what was best for Bella, were two very separate things." Meyer, Midnight Sun, 219. Cf. Rebecca Housel, "The 'Real' Danger: Fact vs. Fiction for the Girl Audience," in Twilight and Philosophy (eds R. Housel et al.), 177-190: "In any world other than the fantastical one created by Meyer, Edward would be jailed” (188).
} 


\subsection{Self-Sacrifice: Christian Subtext}

Both Bella's willingness to vicariously sacrifice herself and Edward's loveinspired but self-punitive, ascetic determination display a Christian subtext. These (here gendered, but related) self-sacrificial scenarios owe their format to a Christian tradition in which both the expiatory and the unifying aspects of sacrifice, traditionally performed by offering sacrificial objects to the gods, have been reformed on the model of Christ's sacrifice, that is, on the model of Christ offering himself vicariously for atonement. In the Christian tradition this format of self-sacrifice resulted in an archetype of ideal moral conduct, based on the idea of the imitatio Christi.

For several decades now, gender-critical scholars in religion have been demonstrating how this seemingly gender-neutral model of ideal Christian conduct worked out to be gender specific from the early centuries onwards. The standards of female virtue and martyrdom did certainly have a lot in common with the ideal Christian virtues held out to men (in fact, philosophers such as Friedrich Nietzsche judge all Christian virtues to be 'feminine'), but in fact ideal female virtue has been disclosed to be more submissive and, above all, more chaste and 'immaculate' than men's. ${ }^{29}$

These gendered differences regarding the actual practice of ideal, selfsacrificial moral conduct can also be noticed in Twilight. Edward admires above all his beloved's kindness: "Bella was good. (...) - kind and self-effacing and unselfish and loving and brave - she was good through and through". ${ }^{30} \mathrm{His}$ own morality, however, is not warm-hearted but tight-lipped, resulting from the willpower he and his family must use to overcome their bloodlust and which, in Edward's case, is being tested to the extreme because of Bella's hyperattractive blood.

Two other male characters in the Twilight narrative, however, display a less stringent kind of self-sacrificial morality: Edward's compassionate vampire father, Carlisle Cullen, and Bella's werewolf friend, Jacob Black. There is no room here to elaborate on the first character's 'super-compassion, ${ }^{31}$ but I want to spend a few words on the latter character. Jacob Black is portrayed as an adolescent of the Quileute tribe, a (genuine) Native American clan living

29 See Cobb, Dying to be men; Glenda McLeod, Catalogs of Women from Antiquity to the Renaissance (Michigan: University of Michigan Press, 1991); and bibliography in Grietje Dresen, Is dit mijn lichaam? Visioenen van het volmaakte lichaam in katholieke moraal en mystiek (Nijmegen: Valkhof Pers, 1998).

3o Meyer, Midnight Sun, 93.

31 Andrew Terjesen and Jenny Terjesen, "Carlisle: More Compassionate Than a Speeding Bullet?” in Twilight and Philosophy (eds R. Housel et al.), 49-6o (59). 
in a reservation near Forks, Washington. In folklore, the Quileute are said to be descended from wolves. This folklore tale is assimilated into the Twilight depiction of (part of) them as a human-werewolf shape-shifting pack, changing shape as soon as they sense menace, especially vampire menace. Jacob's character develops into a rival to Edward for Bella's love. Although throughout the series Bella prefers Edward, Jacob proves to be a genuine, loyal friend by the way he supports and empowers Bella during the numerous complications that go with human-vampire love. Actually, a "Team Jacob" has formed within the worldwide Twilight fandom, uniting fans that prefer Jacob's soft looks and his 'yielding'32 kind of love to Edward's cold, 'white'33 self-discipline. One could say that Jacob's caring love (not only for Bella but, in the last volume, for her half-vampire daughter too) is characterized by a more 'feminine' format of self-sacrifice, despite his werewolf appearances.

"Blood Values": On the Gendered Valuation of Sex-Specific Dealings with Blood

In recent decades, several gender-sensitive scholars of religion have highlighted the distinctive, gendered valuation of the way men and women have dealings with blood, especially in religious or ritualizing contexts. In these contexts, the intentional shedding of blood (not only in sacrifice but also, for instance, in defloration or blood-brother rituals, or in medical and military contexts) is associated with a hallowed, masculine connoted kind of power. The unintentional blood loss that is part of female fertility, however, is generally looked upon as impure. Both anthropological and psychoanalytical scholars have sought an explanation for the common abhorrence of female blood and, on the other hand, for the privileged position of men in blood ritual and other intentional bloodshed. Because a similar, gendered way of dealing with blood features prominently in Twilight, I will outline here the theses of two of these scholars, the French philosopher and psychoanalyst, Julia Kristeva, and the American scholar of religion, Nancy Jay.

32 Cf. Rebecca Housel, "The Tao of Jacob," in Twilight and Philosophy (eds R. Housel et al.), 237-246.

33 Cf. Natalie Wilson, "Civilized Vampires Versus Savage Werewolves: Race and Ethnicity in the Twilight Series" in Bitten by Twilight (eds Click et al.), 55-70. 


\subsection{Julia Kristeva: Abjection and the Horror of Female Blood}

According to Julia Kristeva, the aversion to female blood loss might originate in the ambiguous reactions summoned by what she names the "maternal body". Sensory experiences that reactivate the sense of fusion associated with the maternal body tend to evoke defence, because they pose a threat to self-consciousness and to the capacity to distinguish oneself as a separate and unique individual. As such, these sensations evoke 'abjection', which, according to Kristeva, is:

That state of uncertainty between subject and object that consciousness conceives as abject - state of uncertainty regarding the identity of the self and the other. ${ }^{34}$

Blood, and especially the blood women lose unintentionally, functions as a "matter out of place", as interpreted by Mary Douglas, that is, as a material marker of disorder and lack of control. "Matter out of place" may even symbolize the dangers threatening the boundaries of the social body, especially in times of social instability. Following on from Douglas' hypotheses, Kristeva states:

Excrement and its equivalents (decay, infection, disease, corpse, etc.) stand for the danger to identity that comes from without: The ego threatened by the non-ego, society threatened by its outside, life by death. Menstrual blood, on the contrary, stands for the danger issuing from within the identity (social or sexual); it threatens the relationship between the sexes within a social aggregate and, through internalization, the identity of each sex in the face of sexual difference. ${ }^{35}$

According to Kristeva, the horror provoked by female blood is thus related to the abjection evoked by sensations recalling the maternal body. However, we may assume that the taboos surrounding menstrual blood will also be mingled with awe at the mysterious generative power to which women's "bleeding

34 Bibliographical sources and details on 'abjection' with respect to female blood in Grietje Dresen, "The Better Blood: On Sacrifice and the Churching of New Mothers in the Roman Catholic Tradition," in Wholly Woman, Holy Blood (eds De Troyer et al.), 143-164 (158). 
without dying" testifies. ${ }^{36}$ That at least is the hypothesis underlying the work of Nancy Jay.

\subsection{Nancy Jay: Blood Sacrifice as "Birth Done Better"}

Nancy Jay has been investigating the gendered features of blood sacrifice from the late 1970s until her untimely death in 1991. Her main study on the topic, Throughout Your Generations Forever, was published shortly after her death. Her initial interest in the subject started with the observation that in many societies blood both purifies and pollutes, and that this ambiguity seems to be linked to sex-specific dealings with blood. The voluntary and respected shedding of blood, generally reserved to men, is set against the involuntary blood loss of menstruation and childbirth, which was commonly considered unclean and disqualified women as sacrificial performers. Jay was struck by the way gender had been ignored in most of the anthropological literature on blood sacrificial cults, which is all the more astonishing as most of these cults were accompanied by strict gender-related rules.

After having investigated the function of blood sacrificial rituals within several patrilineal organized kinship structures, Jay concludes that it appears to be a strategy of patrilineal societies to outdo the procreative power of women by incorporating women's mortal children into a spiritual and eternal community bound by the superior, intentional shedding of blood in sacrificial ritual: "The only action that is as serious as giving birth, which can act as a counterbalance to it, is killing". ${ }^{37}$ To interpret and summarize the gendered, both expiatory and communal, transcendental function of blood sacrifice, she introduces the oftquoted description of blood sacrifice as "birth done better": 38

Sacrificially constituted descent, incorporating women's mortal children into an 'eternal' (enduring through generations) kin group, in which membership is recognized by participation in sacrificial ritual, not merely by birth, enables a patrilineal descent group to transcend mortality in the

36 Cf. Dresen, "The Better Blood" and other items in Wholly Woman, Holy Blood (eds De Troyer et al.).

37 Nancy Jay, "Sacrifice as Remedy for Having Been Born of Woman," in Immaculate and Powerful: The Female in Sacred Image and Social Reality (eds C. W. Atkinson et al.; Boston: Beacon Press, 1985), 283-309.

38 Jay, "Sacrifice as Remedy for Having Been Born of Woman," passim. Also passim in Jay, Throughout Your Generations. 
same process in which it transcends birth. In this sense, sacrifice is doubly a remedy for having been born of woman. ${ }^{39}$

Jay's interpretations regarding the mortality-transcending functions of blood sacrifice have often been modified or even criticized. She would have agreed to that, however, because she considered the concepts she used to be "lenses that will bring into focus analogous aspects of differing traditions", and compared the continuing process of interpretation with women's work, "never done but not consequently invalid". 40 I will make grateful use of her lenses in my analysis of the "blood values" in Twilight, focusing on the protagonists' gendered dealings with blood.

\section{3 "It was a God Complex": Edward's Bloodlust as Control Over Life and Death}

One of the first things that strikes Bella in the overall intriguing appearance of Edward is the colour of his eyes, changing from black to amber, and back. When she later learns he is a vampire, she hears the cause: Normal vampires, living on human blood, have fiery red eyes, but the Cullens' eyes change to a warm-golden amber when they have consumed their diet of animal blood. Little by little this amber discolours to black again, indicating they urgently need a fresh input of blood. The animal blood diet does not still their thirst for human blood, yet it makes that thirst bearable. Throughout the series, the golden colour of the Cullens' eyes is used to symbolize their unique vampire morality and bloodlust control; it serves as a marker, "a reflection of a mutual choice". ${ }^{41}$ No doubt is left, however, about the constant threat of their razorsharp teeth and the venom behind. When Edward first meets Bella, in the biology classroom, this threat is articulated, in his voice, as being one of the two faces in his head:

One was mine, or rather had been:The red-eyed monster that had killed so many people (...). It was a god complex, I acknowledged that - deciding who deserved a death sentence. (...) The other face was Carlisle's. There was no resemblance between the two faces. They were bright day and blackest night. ${ }^{42}$

\footnotetext{
39 Jay, Throughout Your Generations, 40.

40 Jay, Throughout Your Generations, 13; 23.

41 Meyer, Midnight Sun, 13.

42 Meyer, Midnight Sun, 12.
} 
But there is no doubt left either about the face that 'wins': Carlisle's face, with the soft golden eyes. The relationship between the protagonists changes from that of a 'predator' being attracted to his 'prey', ${ }^{43}$ into a mutual crush between 'lion' and 'lamb'. This still seems a threatening situation, but the thrill is willingly accepted from both sides. ${ }^{44}$

The thrill of this gendered human-vampire crush is evoked again and again throughout the series, and highlighted in lengthy descriptions (or film sequences) of Edward's lips lingering above Bella's silky throat. Several critics pointed to the close connection between bloodlust, sexual desire and death in Twilight. Of course this connection characterizes all vampire stories (which, in their turn, borrow the associative causality between lust, sex and death from the Christian tradition), but in modern, atypical vampire narratives such as Twilight the principal undead figures are not the creepy, bloodsucking intruders any more. In Twilight, the vampire-classical, masculine-gendered association between bloody violence, sexual transgression and (im)mortality has been stretched to make room for civilized, literally shiny ${ }^{45}$ creatures like the Cullens (while the antagonist vampires continue to be creeps, in varying degrees). Edward even manages not only to control his lust for Bella's alluring blood but also to distinguish this lust from his being sexually attracted to her ("A new kind of desire was growing in me, working to override my self-control") ${ }^{46}$ and then to control this latter temptation too. The urge of his instincts makes him perceive Bella as utterly fragile, "silk over glass":

You don't realize how incredibly breakable you are. I can never, never afford to lose any kind of control when I'm with you. ${ }^{47}$

However, after being married, old school Edward gives in to their sexual desires, and even succeeds in controlling his bloodlust through the passion of their first night (though leaving Bella covered with bruises).

43 Meyer, Midnight Sun, 10.

44 Meyer, Twilight, 240: “'And so the lion fell in love with the lamb' ... he murmured. I looked away, hiding my eyes as I thrilled to the word. 'What a stupid lamb', I sighed. 'What a sick, masochistic lion'." Twilight merchandising has gratefully exploited the first sentence quoted.

45 The Twilight vampires tolerate sunlight, but in the sun their marble like skin sparkles as if it were covered with diamonds.

46 Meyer, Midnight Sun, 250.

47 Meyer, Twilight, 271 (emphasis in original). 
Over against the classical vampire as a symbol of transgression, sacrificing innocent life on the altar of his lust, Edward's control over his bloodlust and his sexual lust symbolizes the high values that come with it. By his utter control, the sequence of lust, transgression and death (a sequence related to what Augustine termed original sin) is temporarily suspended. Edward may not have a soul, as he does not cease to emphasize, his continence is truly superhuman, or in fact heavenly, in the Augustinian sense. ${ }^{48}$ When finally he does have to transform Bella because she is dying in childbirth, covered in blood, he does so in an extremely controlled performance, both clinical and sensual, by first injecting his venom into her heart with a silver syringe, then carefully biting her all over her body, sealing the wounds with his tongue to keep the venom inside. By this solemn, ritual-like enactment, the transformation that was postponed throughout the narrative, is executed. That is to say, it is started, for Bella will have to burn on her 'pyre' 49 for three days, suffering unbearable inner pain, before the transformational process from human into vampire will be finished and the creation of new substance completed - comparable to the transformational process by burnt offering in Vedic sacrifice. The values that come along with Edward's control of his bloodlust are most clearly depicted in the scene in which new born vampire Bella goes out for her first hunt with him. Bella makes a mess of herself, with animal blood all over her, but Edward manages to kill and drain a deer without spilling a drop of blood:

$[\mathrm{N}]$ ot a hair ruffled, not a spot on his white shirt. (...) I watched carefully to see how he was able to hunt so neatly. ${ }^{50}$

So Bella's sacrificial executor is a godlike decider of life and death, a vegetarian ascetic inspired by humanist, not to say Christian, values, and a blinding white, neatly hunting bloodsucker (and a good lover, too!). His sacrificial power is closely connected to his planned shedding of blood, or refraining from doing so, in performances that display his superhuman control. As a result of this control, Bella can be incorporated into the loving, everlasting communion of the Cullens.

48 Cf. Michael Müller, Die Lehre des Hl. Augustinus von der Paradiesesehe und ihre Auswirkung in der Sexualethik des 12. und 13. Jahrhunderts bis Thomas von Aquin (Regensburg: Pustet, 1954). Augustine's anthropology is central to the theology of Meyer's Mormon Church.

49 Meyer, Breaking Dawn, 389. The process of inner burning and the excruciating pain accompanying it is depicted from p. 375 onwards.

5o Meyer, Breaking Dawn, 424. 


\subsection{Bella's Blood: Temptation, Danger and Distress}

The covers of the Twilight book series all have a simple, symbolic image in red and white against a black background. In the context of the respective imagery, the distinct red always refers to Bella's blood and its pivotal meaning in the narrative, particularly to her dangerous attraction for Edward and her fragility both human and feminine. ${ }^{51}$ In Twilight (and especially in Edward's version of the story, Midnight Sun), mention of Bella's blood always implies lust, and thus danger. There is notable progress as to the acuteness of that danger, though; the scent of her blood first hit Edward like a "wrecking ball", but later on he manages to "appreciate the bouquet", even though he will not drink the wine ${ }^{52}$ and calls it "exactly my brand of heroin". ${ }^{33}$ Apart from the scent, it is the substance, "hot, wet and pulsing",54 behind the rosiness of Bella's skin that continues to tantalize Edward. He is not the only vampire to notice her extraordinary attraction, however; most of the complications in the storyline evolve, one way or another, out of this fictional fact. The attraction of her blood for vampires is a given that goes beyond Bella's will. Within the narrative, it is associated with her utter fragility and vulnerability: In the first three volumes, being an attractive 'snack' ${ }^{55}$ poses constant threats to her. Even during her visits to the wellcontrolled Cullens, a paper cut in her finger or a broken glass bowl are enough to cause general panic.

So the key connotations of Bella's blood in the Twilight Saga are temptation (from a vampire's perspective) and thrill, danger or distress, from the reader's or viewer's perspective, which is connected to Bella's view, as she is the main narrator. Sometimes it is Bella herself who mentions her own blood as a metaphor for desire running out of control. For example during the lovers' first, tentative touch:

My blood was racing, and I wished I could slow it, sensing that this must make everything so much more difficult - the thudding of my pulse in my veins. ${ }^{56}$

51 On the cover of Twilight, a red apple evokes the symbolism of the Fall. On the New Moon cover, a withering white and red tulip (losing a feather-like red petal) represents ephemeral beauty and Bella's mourning. On the Eclipse cover, an almost torn red ribbon symbolises Bella trying to break away from her human life. On the final volume, a little red pawn, standing behind a tall white chess queen, represents the human shape Bella left behind.

$5^{2} \quad$ Meyer, Twilight, 267.

53 Meyer, Twilight, 235 .

54 Meyer, Midnight Sun, 14.

55 Meyer, Twilight, 331.

$5^{6}$ Meyer, Twilight, 241. 
At their first kiss, 'racing' even turns into 'boiling':

Edward hesitated to test himself (...), to make sure he was still in control of his need. And then his cold, marble lips pressed very softly against mine. What neither of us was prepared for was my response. Blood boiled under my skin, burned in my lips. (...) Immediately I felt him turn to unresponsive stone beneath my lips. (...) "Oops", I breathed. "That's an understatement." His eyes were wild, his jaw clenched in acute restraint, yet he didn't lapse from his perfect articulation. (...) "Wait for a moment, please." His voice was polite, controlled. ${ }^{57}$

In contrast to Edward's control, Bella's racing and boiling blood emerges as a mark of wild, unruly desire.

As to Bella's own intentional dealing with blood, her character shows a striking development, going from fainting in class at the mere sight of a drop of blood in Twilight, , $^{58}$ to deliberately cutting her arm in order to distract hostile vampires from killing Edward at the end of Eclipse, to drinking human blood (provided by Carlisle from his medical blood bank) to prevent her unborn halfvampire baby from draining her from within in Breaking Dawn. The final step in this sequence of Bella's dealing with blood is the aforementioned first hunt with Edward, during which she ruins her clothes with blood, but shows unprecedented self-control when they inadvertently stumble on human passers-by. Newborn vampires are known for not being able to resist human blood, but Bella just runs the other way to prevent herself from pouncing on them. This unseen newborn control also enables her to nurture her hybrid daughter, who combines a blood circulation with vampire features.

\subsection{Female Sexuality and Bella's Unintended and Intentional Dealings with Blood}

There is another semantic field (associated with that of temptation and danger) that is attached to the mention of Bella's blood. The passages referring to her racing and boiling blood also denote this field. It is the field of female sexuality, here presented in terms of its traditional Christian valuation as a threat to male rationality - and as such paralleling the references to Edward's ideal continence. Thanks to Edward's control, Bella can unleash her desires, which are being depicted at length throughout the series. In the final volume, these desires and their consumption 'materialize' in Bella's becoming pregnant with

57 Meyer, Twilight, 247.

$5^{8}$ In chapter 5 : "Blood type". 
a child that threatens to kill her, because of its rapid growth. The beginning of this pregnancy, which is also the starting point of her transformation, is marked by Bella noticing that her menstruation (the 'curse') has stopped..$^{59}$ The rapid growth of the foetus will eventually break her ribs and even her spine, forcing Edward to cut the baby out. The child is born in a fountain of blood, leaving Bella as a Christ taken from the cross, a "broken, bled out, mangled corpse".60 After being bitten into vampire existence, however, all her fatal injuries vanish; all her human and female weaknesses are gone. Her vampire appearances make her look like "a carving of a goddess"; her new, "bloodless' sovereignty is symbolized on the cover of Breaking Dawn by the white chess queen. As a vampire, Bella thus transcends the frailties, flaws and pains that come along with Eve's curse. Her sex appeal is obviously not reduced, though; but both lovers are finally equal in beauty, strength and erotic agency.

Summarizing the values that Bella's blood and her dealing with blood stand for, we must distinguish not just between the period before and that after her transformation, but in particular between the blood Bella involuntarily displays through her fragrance and alluring skin or loses because of her female fertility, and her more or less intentional dealing with blood. The blood loss that is women's part of the Fall (and that, within Bella's part in Twilight, is enlarged to the ridiculous) comes to an end with her transformation. Thereafter, she is as strong, closed, controlled and marble-white as her new vampire family. In sharp contrast to this new looks, her alluring blood and unintended blood loss during delivery (described in details through Jacob's eyes) evoke abjection, in the sense that Julia Kristeva has given to that term.

As for Bella's intentional dealing with blood, her change is gigantic. It could be summed up in her own words, as in the Preface of the third book, Breaking Dawn): "The panic changed to bloodlust".61 As such, her transformation reflects quite literally the dynamics of "rebounding violence" that the British scholar of ritual, Maurice Bloch, has described in his study on the function of blood sacrifice, Prey into hunter. ${ }^{62}$ In a similar dynamic of "prey into hunter",

\footnotetext{
59 Meyer, Breaking Dawn, 123.

$60 \quad$ Meyer, Breaking Dawn, 355 .

61 Meyer, Breaking Dawn, 368.

62 Maurice Bloch, Prey into hunter: The politics of religious experience (Cambridge: Cambridge University Press, 1992). Bloch uses the symbolism of prey and hunter to explain the symbolic violence enacted in sacrificial ritual. By this ritually re-enacted violence (named as 'rebounding violence'), the participants in sacrifice are transformed and their mortal transience is converted into being a participant in a transcendent entity. Clearly, this symbolism and Bloch's explanation resemble Jay's description of blood sacrifice as 'birth done better. However, Bloch does not reflect upon the fact that the role of women in sacrifice
} 
post-transformation Bella is included into the Cullens' communion of mortality-transcending vegetarian hunters.

\section{Bella's Transformation, or: Becoming Who You Are}

I return to the question in my introduction: What captivates the countless fans in this romantic vampire story that apparently represents such traditional values? There is no doubt that this fascination exists, first of all, in the "erotics of abstinence" that are expressed throughout the Twilight Saga. Nevertheless many critics have lamented the glorification of the female protagonist's dependent character. Why are the devotees (many of whom suffer from selfdiagnosed "Obsessive Twilight Disorder") ${ }^{63}$ not irritated by this dependency?

I suggest that the answer to this question must not only be sought in Edward's (and Jacob's) thrilling beauty, strength and composure, but also in characteristics of Bella with which fans can identify. Apart from the space for female (heterosexual) desire that is created through Edward's continence, an appealing feature of Bella's role appears to be her uniqueness, being chosen for eternity and, within this election, Edward's very serious recognition of her vulnerability and fragility. Critics may deplore this ascription, but I think they must have forgotten how it feels to be a teenager. Being an adolescent (and a female adolescent, in particular) in a culture in which beauty and decisive agency are being overrated can make you feel very insecure if you do not yet know your own qualities. Bella is such a teenager not yet knowing her qualities. She is just a plain, unselfish girl. A girl that is initially noticed by Edward because of her "mind shield" that prevents him from reading her thoughts. Despite that mind shield, he recognizes her uncertainty and 'vulnerability'. I suppose that this outward recognition of Bella's vulnerability is reassuring, especially for fans who sense themselves to be just as vulnerable. It makes Bella's election even more special. A godlike lover that notices and respects your vulnerability: What teenager would not want that?

is usually strictly limited (although he mentions this fact, e.g. on p. 69: "[W]omen who are not virgins, especially menstruating women, are excluded from many aspects of the cults.") Also he ignores the fact that in many cultures (e.g. in Christianity) women (here: as Eve's daughters) are held responsible for mortal transience. An obliviousness that Jay showed to be common in studies on blood sacrifice.

63 Steven D. Greydanus, "Twilight Appeal: The cult of Edward Cullen and vampire love in Stephenie Meyer's novels and the new film" (2008), on www.decentfilms.com/articles/ twilight (visited October 29, 2011). 
After her transformation, it is exactly her mind shield that proves to be Bella's 'gift'. Most of the vampires in Twilight have a special gift; Edward's gift is his mind-reading, for example. These gifts tend to be an enlargement of the most characteristic quality they had when they were still human. Despite Bella's apparent clumsiness as a human teenager, her mind shield appears to be interrelated with her capacity for self-control: "Then I realized what that might mean, if my 'superpower' was no more than exceptional self-control".64

This capacity for self-control was being symbolized and fictionally 'materialized' in the shield enabling Bella to protect her mind against the invasive gift of Edward and other vampires. She takes this protective shield with her into eternity. As the Saga runs toward the final battle (a battle with the reigning vampires, the Volturi, who want to kill her hybrid child) it turns out that Bella can externalize her shield and wrap it around those she loves as a protective cloak. So the quality Bella was unaware of when a teenager was her unusual capacity to protect her own mind; and she can use this same, now literally extended, capacity after her transformation to protect those she loves from unwanted intrusion. Externalizing and stretching her shield requires a lot of her self-control, but once she succeeds she operates on the battleground as a Madonna of the protective cloak. ${ }^{65}$ Or, indeed, as the cloaked chess queen on the final cover, being a symbol of idealized female power. Bella even succeeds in temporarily lifting her mind shield for Edward, which appears to be even harder than wrapping it around those she loves. She gives him a glimpse of her thoughts, lingering on their most exciting moments up till then:

I knew my shield better now. I understood the part that fought against separation from me, the automatic instinct to preserve self above all else. It still wasn't anywhere as easy as shielding other people along with myself. I felt the elastic recoil again as my shield fought to protect me. (...) I concentrated even harder, dredging up the specific memories I'd saved for this moment.66

Many critics deplored the unrealistic romanticism of this vampire fantasy (“Unlike Bella, we don't have the option of awakening to an eternal life or

\footnotetext{
64 Meyer, Breaking Dawn, 466.

65 On Mary as a 'bloodless', yet empowering symbol of ideal female power (similar to Bella's post-transformation figure), see Cleo McNelly Kearns, The Virgin Mary, Monotheism, and Sacrifice (Cambridge: Cambridge University Press, 2008).

66 Meyer, Breaking Dawn, 752-753.
} 
experiencing undying romance" $)^{67}$ and saw this as an escape from our human condition. Fans, however, are well aware that Twilight's characters are fictional, as is shown by their comments and narrative revisions on fan blogs. ${ }^{68}$ Reading Twilight might indeed imply a temporary escape from reality, as reading fiction always does. Yet I trust that while enjoying this escape, fans do not appreciate Bella Swan as a model of second-sex compliance, but rather as an example of Nietzsche's "becoming who you are" or as a duckling proving to be a swan (as her name already indicates). Certainly, Twilight readers cannot become immortals themselves, but the good news is that they know this perfectly well.

Julia Kristeva aptly described adolescence as a "syndrome of ideality" (referring to processes of idealization as understood by Melanie Klein): "The adolescent believes that the Great Other exists and is pleasure itself". ${ }^{69}$ Twilight undeniably reflects such Great Others. However, experiencing pleasure from fictional Great Others is less harmful than believing they really exist.

67 Jennifer L. McMahon, "Twilight of an Idol: Our Fatal Attraction to Vampires," in Twilight and Philosophy (eds Housel et al.), 193-208 (206).

68 Cf. Bitten by Twilight (eds Click etal), Part II: "Biting into the Twilight Fandom," 137-222 (5 chapters).

69 Julia Kristeva, "Adolescence, a syndrome of ideality," in Psychoanalytic Review 94 (2007): 715-725 (719). Cf. Julia Kristeva, "The Adolescent Novel," in Abjection, Melancholia, and Love: The Work of Julia Kristeva (eds J. Fletcher and A. Benjamin; London \& New York: Routledge, 1990), 8-23. 